\title{
ABOUT THE AUTHORS
}

\author{
EDITORS
}

\section{Iris H-Y Chiu (Editor)}

Iris is a Reader in Law at University College London, and her research expertise lies in financial regulation and corporate governance. She has published extensively on corporate governance, as well as regulatory theories and governance in the financial sector, in over 20 peer-reviewed journals in the UK and US. She has published a number of books including Regulatory Convergence in EU Securities Regulation (Wolters Kluwer 2008) which deals with EU securities regulation and a systemic analysis of harmonisation in the law in books as well as the law in action; The Foundations and Anatomy of Shareholder Activism (Hart Publishing 2010) which deals with the legitimacy issues surrounding various forms of shareholder activism in the UK and EU; and The Foundations and Future of Financial Regulation (Routledge, 2014, co-authored with Mads Andenas). Her books have been well received (see positive reviews of the Shareholder Activism title, Katelouzou, JCLS 2012, and Masouros, JBL 2011). She is executive editor of the European Business Law Review and co-series editor of the Palgrave Macmillan Corporate and Financial Law Series. She was a Visiting Professor of Law at Singapore Management University (2014).

\section{Michael McKee (Consulting editor)}

Michael McKee is a partner and Head of Financial Services Regulation at DLA Piper UK LLP. Michael has many years of advising clients and working with financial institutions and regulators in the UK, in Europe and internationally. He is an Executive Board member of the UK's International Regulatory Strategy Group which develops financial services strategy for the UK's financial services industry. He has been appointed to a number of European Union bodies and groups in the past working on EU financial services legislative issues and has given evidence to both the European Parliament and the House of Lords on such issues.

\section{CONTRIBUTORS}

\section{Anna P Donovan}

Anna is a Lecturer at UCL Laws and an advisory board member of the Faculty's Centre for Ethics and Law. Anna's research expertise lies in corporate governance and regulation, with a specific focus on corporate compliance strategies and anti-corruption measures. Prior to UCL, Anna was a senior corporate solicitor in London, specialising in corporate restructuring and governance where she advised boards extensively on their corporate governance obligations. During her time in practice Anna a was a principal 
author of both editions of $A$ Practical Guide to the Companies Act 2006-A Guide for Busy Directors and Company Secretaries (2nd edn, CCH 2010). Anna is also a qualified attorney, admitted to the New York bar.

\section{Rod Edmunds}

Rod joined Queen Mary University of London as a Senior Lecturer in 2003. He previously held academic appointments at Sussex University and the University of Nottingham, and also held the post of Director of Education at D J Freeman \& Co in London.

\section{Andreas Kokkinis}

Andreas is a Teaching Fellow at the University of Warwick and teaches both at the undergraduate and postgraduate degrees. Prior to that Andreas taught at UCL Laws, Kent Law School and the University of Buckingham School of Business. He holds a PhD from UCL (2014), an LLM (Distinction) from LSE (2009) and an LLB (Distinction) from the National University of Athens (2008). He has undertaken professional legal training in Greece and is a qualified advocate, member of the Athens Bar Association since 2011. Andreas' doctoral research was on the corporate governance of banks in the UK and focused on whether banks present unique governance problems that have to be addressed by bank-specific corporate governance rules, with a view to ensuring the sustainable development of the banking industry. Andreas has been honoured by several academic awards including a PhD scholarship from the Greek State Scholarships Foundations, the 1 Essex Court LLM Prize for the best performance in Corporate Law during the 2008-09 academic year in LSE and Achilles Balis Foundation prize in 2008 for his overall performance during his LLB in Athens' Law School. Andreas' publications include: 'The reformed "fit and proper" test: A call for a broader rethink of bank corporate governance?' (2012) 9(1) International Corporate Rescue and 'Rethinking banking prudential regulation: Why corporate governance rules matter?' (2012) 7 Journal of Business Law 611.

\section{John Lowry}

John is Chair of Commercial Law at Hong Kong University, and Emeritus Professor of Commercial Law at UCL. He has taught law in the USA and practised in Canada specialising in corporate litigation. He has written widely in domestic and international journals on directors' fiduciary obligations, shareholder remedies and insurance law. $\mathrm{He}$ is co-author of a number of books including, Limitation of Actions (LLP, 1998); Company Law (OUP 2012); Pettet's Company Law (Pearson 2014); Insurance Law: Doctrines and Principles (Hart 2011); and Insurance Law: Cases and Materials (Hart 2004). He is also a contributing editor to Gore-Browne on Companies (Jordans) and Annotated Companies Legislation (OUP). He is a member of a number of editorial boards, including the Journal of Business Law, Company Lawyer and International Corporate Rescue. In 2001 he was a Visiting Fellow at the University of Connecticut and he was made an Honorary Fellow of Monash University in 2009. In 2010 he was elected Distinguished Global Jurist Visiting Professor at the Chinese University of Hong Kong. 


\section{Marc T Moore}

Marc is Reader in Corporate Law and Director of the Centre for Corporate and Commercial Law (3CL) in the Faculty of Law, University of Cambridge. He is also a Fellow of Murray Edwards College, Cambridge; an Honorary Reader in the Faculty of Laws, University College London; and Deputy Chief Examiner for Company Law on the University of London's external LLM programme. Marc has previously held teaching positions at University College London, the University of Bristol, and Seattle University. Marc's principal area of expertise is Anglo-American corporate law and governance. He has authored and co-authored a number of articles and papers in this field within leading international publications. In 2013 his book, Corporate Governance in the Shadow of the State (Hart Publishing 2013), was shortlisted for the SLS Peter Birks Prize for Outstanding Legal Scholarship. In 2012, Marc was awarded a Philip Leverhulme prize in recognition of outstanding research achievement to date. Marc is a commissioning editor of a new Palgrave-Macmillan text series on corporate and financial law, and in 2010 he was UK national reporter on corporate governance for the XVIIIth Congress of the International Academy of Comparative Law at Washington DC.

\section{Arad Reisberg}

Arad is currently a Reader in Corporate and Financial Law and Director, UCL Centre for Commercial Law. He acted as Vice Dean (Research) at UCL Faculty of Laws between 2009-12. He has been teaching at the Faculty since September 2003, and joined it full time in September 2006. He was formerly a Senior Arts Scholar (2001-03) and a Tutor at Pembroke College Oxford, where he taught law at six colleges at Oxford University between 2001-05. He has also been a Visiting Lecturer at Oxford University (2005) and more recently, a Visiting Professor of Law at Brooklyn Law School (Fall Term 2012), and a Visiting Professor of Law at NUS (2014). He is the recipient of numerous academic scholarships and awards and has written widely on shareholder remedies and directors' duties. Arad is the author of Derivative Actions and Corporate Governance (OUP 2007), the first book to provide a detailed and theoretical explanation of the law governing derivative actions. He is also an Academic Member of ECGI (European Corporate Governance Institute), a co-editor of Pettet's Company Law, sits on the editorial boards of the International Corporate Rescue and the Journal of Corporate Ownership and Control, and is a contributing author to Annotated Companies Legislation (OUP).

\section{Georgina Tsagas}

Georgina is a Lecturer in Law at the University of Bristol Law School and her research expertise lies in takeover regulation and corporate governance. She has formerly held posts at University College London, Faculty of Laws, as a Postdoctoral Research Associate (2013-14) (and at Queen Mary University of London, School of Law, as a Teaching Fellow (2010-2012). Georgina holds a PhD from Queen Mary University of London sponsored by a Full Scholarship (2009-12) award from QMUL School of Law. She has written on the prospective reform of the EU Takeover Directive and the changes to the UK City Code on Takeovers and Mergers following the reform 
prompted by the Kraft-Cadbury deal in 2011. Georgina is a qualified Solicitor of England and Wales and an attorney-at-law in Greece. She has lectured on the LLM and LLB programmes at UCL, Centre for Commercial Law Studies, QMUL and BPP Law School respectively and has acted as a guest academic tutor at LSE Summer School. Her recent publications include: 'A long-term vision for UK Firms? Reconsidering target director's advisory role post the takeover of Cadbury's plc' (2014) 14(1) Journal of Corporate Law Studies 241 and 'The revision of the EU Takeover Directive in light of the 2011 UK takeover law reform' (2013) 10(1) International and Comparative Company Law Journal 21.

\section{Edward Walker-Arnott}

Edward is a Visiting Professor at UCL's Faculty of Laws. He has been with Herbert Smith Freehills throughout his professional career and was senior partner between 1992-2000. He sat on the Departmental Committee (the Cork Committee) inquiring into insolvency law between 1977-82. The report resulted in the enactment of the Insolvency Act 1986. At the beginning of 1983, Edward was appointed one of the first three nominated members of the Council of Lloyd's, sitting on the Council for six years. He chaired the Investigations Committee at Lloyd's, which conducted the investigations of the many Lloyd's scandals of the late 1970s and early 1980s and prosecuted the subsequent disciplinary proceedings. He is well known in the City having been involved in many high-profile cases including a number of celebrated take-over battles.

Edward has also served as Governor of the South Bank Centre between 1999-2009; he was on the Board of the Royal National Theatre from 2000-08 and served as Governor of the Wellcome Trust from 2000-10. Edward is currently a non-executive director of a private company with significant commercial and property interests in the UK and in Europe and of a biotech start-up company backed by both the Wellcome Trust and the Gates Foundation. He is a member of the Takeover Appeal Board and was made a QC (Hon) in 2013. 